\title{
Lung function in the absence of respiratory symptoms in overweight children and adolescents*
}

\author{
Função pulmonar de crianças e adolescentes sem \\ sintomas respiratórios e com excesso de peso
}

\author{
Silvana Neves Ferraz de Assunção, Carla Hilário da Cunha Daltro, \\ Ney Christian Boa Sorte, Hugo da Costa Ribeiro Júnior, Maria de Lourdes Bastos, \\ Cleriston Farias Queiroz, Antônio Carlos Moreira Lemos
}

\begin{abstract}
Objective: To describe lung function findings in overweight children and adolescents without respiratory disease. Methods: This was a cross-sectional study involving male and female overweight children and adolescents in the 8-18 year age bracket, without respiratory disease. All of the participants underwent anthropometric assessment, chest X-ray, pulse oximetry, spirometry, and lung volume measurements. Individuals with respiratory disease were excluded, as were those who were smokers, those with abnormal chest $X$-rays, and those with an $\mathrm{SpO}_{2} \leq 92 \%$. Waist circumference was measured in centimeters. The body mass index-for-age $Z$ score for boys and girls was used in order to classify the individuals as overweight, obese, or severely obese. Lung function variables were expressed in percentage of the predicted value and were correlated with the anthropometric indices. Results: We included 59 individuals ( 30 males and 29 females). The mean age was $11.7 \pm 2.7$ years. Lung function was normal in 21 individuals (35.6\%). Of the 38 remaining individuals, 19 (32.2\%), 15 (25.4\%), and $4(6.7 \%)$ presented with obstructive, restrictive, and mixed ventilatory disorder, respectively. The bronchodilator response was positive in 15 individuals (25.4\%), and TLC measurements revealed that all of the individuals with reduced $\mathrm{VC}$ had restrictive ventilatory disorder. There were significant negative correlations between the anthropometric indices and the Tiffeneau index in the individuals with mixed ventilatory disorder. Conclusions: Lung function was abnormal in approximately $65 \%$ of the individuals evaluated here, all of whom were overweight. Obstructive ventilatory disorder and positive bronchodilator response predominated.
\end{abstract}

Keywords: Obesity/complications; Respiratory function tests; Lung diseases/etiology.

\section{Resumo}

Objetivo: Descrever os achados de função pulmonar em crianças e adolescentes sem doenças respiratórias e com excesso de peso. Métodos: Estudo transversal com crianças e adolescentes de 8 a 18 anos de ambos os sexos, com excesso de peso e sem doença respiratória, submetidos à avaliação antropométrica, radiografia de tórax, oximetria de pulso, espirometria e medidas de volume pulmonar. Indivíduos com patologias respiratórias, tabagistas ativos, radiografia anormal ou $\mathrm{SpO}_{2} \leq 92 \%$ foram excluídos do estudo. A circunferência da cintura foi medida em centímetros. 0 escore z para índice de massa corpórea/idade e sexo foi utilizado para classificar os indivíduos como com sobrepeso, obesos e obesos graves. As variáveis dos testes de função pulmonar foram expressas em percentual do previsto e correlacionadas com os índices antropométricos. Resultados: Foram incluídos 59 indivíduos (30 meninos e 29 meninas). A média de idade foi de 11,7 $\pm 2,7$ anos. Os resultados dos testes de função pulmonar foram normais em 21 indivíduos (35,6\%). Dos 38 indivíduos restantes, 19 $(32,2 \%), 15(25,4 \%)$ e $4(6,7 \%)$ apresentaram, respectivamente, distúrbio ventilatório obstrutivo, restritivo e misto. A resposta ao broncodilatador foi positiva em 15 indivíduos $(25,4 \%)$, e a medida da CPT revelou que todos os indivíduos com CV reduzida apresentavam distúrbio ventilatório restritivo. Houve correlações negativas significantes entre os índices antropométricos e índice de Tiffeneau nos indivíduos com distúrbio ventilatório misto. Conclusões: A função pulmonar apresentou-se alterada em aproximadamente 65\% dos indivíduos com sobrepeso aqui avaliados, predominando distúrbio ventilatório obstrutivo e resposta positiva ao broncodilatador. Descritores: Obesidade/complicações; Testes de função respiratória; Pneumopatias/etiologia.

*Study carried out at the Professor Edgard Santos University Hospital, Federal University of Bahia School of Medicine, Salvador, Brazil. Correspondence to: Silvana Neves Ferraz de Assunção. Avenida Juraci Magalhães Júnior, 1665, Quadra 03, Lote 05, Rio Vermelho, CEP 40295-140, Salvador, BA, Brasil.

Tel. 5571 3283-8034. E-mail: snfassuncao@oi.com.br

Financial support: None.

Submitted: 30 September 2013. Accepted, after review: 12 December 2013. 


\section{Introduction}

Obesity is a multifactorial chronic disease that is epidemic worldwide. ${ }^{(1)}$ Because of the socioeconomic impact, morbidity, and mortality of obesity, there has been growing interest in understanding the disease. ${ }^{(2)}$ Impaired lung function is a possible complication of obesity and is often overlooked, despite occurring in a manner that is similar to that observed in other diseases, such as cancer, cardiovascular disease, and chronic respiratory disease. ${ }^{(3)}$ Lin at al..$^{(4)}$ reported that various obesity-related cytokines can contribute to systemic inflammatory effects in individuals with obstructive airway disease and sleep apnea syndrome.

Although obesity-related lung function changes have been described in adults, there is a lack of data on such changes in children. ${ }^{(5)}$ The increase in childhood obesity is an emerging problem worldwide and directly contributes to obesity in adulthood; as a result, there is an increase in the incidence of fatal diseases such as cardiovascular disease, metabolic syndrome, dyslipidemia, diabetes mellitus, arterial hypertension, and even respiratory changes. ${ }^{(6)}$

Methodological differences across studies in terms of the diagnostic evaluation of obesity and the selection of a well-characterized population make direct comparisons difficult and underscore the need for further studies. In view of these considerations, the objective of the present study was to describe lung function changes in overweight children and adolescents without respiratory symptoms.

\section{Methods}

This was a cross-sectional descriptive study involving male and female overweight patients in the 8-18 year age bracket. Age was recorded in completed whole years, and skin color/ethnicity was classified as black (African), brown (Mulatto), white (Caucasian), yellow (Asian), or red (Indigenous) on the basis of the parameters established by the Brazilian Institute of Geography and Statistics. (7) A convenience sample was recruited between May of 2010 and September of 2011 from among patients treated at the child and adolescent obesity outpatient clinic of the Pediatric Clinical Nutrition Department of the Professor Edgard Santos University Hospital, located in the city of Salvador, Brazil. The participants completed a systematic questionnaire designed for the present study and including data obtained during history taking and physical examination (with emphasis on respiratory findings), ancillary tests being subsequently performed. The inclusion criteria were as follows: having exogenous obesity; having no respiratory symptoms; having normal pulmonary auscultation and chest $\mathrm{X}$-ray findings; and having a baseline $\mathrm{SpO}_{2}>92 \%$. Neither smokers nor patients with a history of wheezing, cough, chest pain, or respiratory disease were included in the present study.

Waist circumference was measured with a flexible, nonelastic tape measure at the midpoint between the lower costal margin and the anterior superior iliac crest. ${ }^{(8)}$ Two measurements were performed, and the mean was used. Participants were weighed (in their underwear) on a portable scale (Filizola, São Paulo, Brazil) accurate to within $100 \mathrm{~g}$. Height (in $\mathrm{cm}$ ) was measured to the nearest $0.1 \mathrm{~cm}$ with a stadiometer with a base plate. The body mass index (BMI) was calculated by the formula weight/height ${ }^{2}(\mathrm{~kg} /$ $\mathrm{m}^{2}$ ), and the World Health Organization (WHO) BMl-for-age Z score for girls and boys ${ }^{(9)}$ was used to classify the participants as overweight (having a $\mathrm{BMI}>1 \mathrm{SD}$ above the WHO growth standard median), obese (having a BMl $>2$ SDs above the WHO growth standard median), or severely obese (having a BMI > 3 SDs above the WHO growth standard median).

Lung function was assessed in the Pulmonary Function Laboratory of the Federal University of Bahia, located in the city of Salvador, Brazil. Lung function was assessed by spirometry with pharmacological testing, spirometry being performed with a Koko Digidoser pneumotachograph spirometer (Ferraris Respiratory, Louisville, CO, USA). The tests were performed before and $15 \mathrm{~min}$ after the administration of $400 \mu \mathrm{g}$ of inhaled albuterol. The helium dilution method was used in order to measure RV and TLC, which were measured with a Vmax 21 mass flow sensor (Viasys Healthcare, Palm Springs, CA, USA). Participants were advised to refrain from coffee, tea, medications (such as bronchodilators), and large amounts of food before the tests. Participants performed the tests with their heads in a central position, using a nose clip. All tests were performed at the same time of day (in the afternoon) by the same professional. At least three FVC maneuvers were performed by each 
individual; the tests and curves that met the acceptability and reproducibility criteria of the American Thoracic Society ${ }^{(10)}$ and the Brazilian Thoracic Association ${ }^{(11)}$ were selected. The highest of at least three technically acceptable measurements of FEV and FVC were selected. Those were expressed as absolute values and as percentages of predicted values, the latter being defined as the lower limit of normal (LLN) for each individual. The LLN was calculated by the equation described by Pereira, ${ }^{(12)}$ valid for both genders. The reference values for lung volumes (RV and TLC) were those reported by Pennock et al. ${ }^{(13)}$

On the basis of spirometric values, TLC, and $\mathrm{RV}$, patients were classified as having one of the following:

- normal lung function-FVC $\geq$ LLN; FEV 1 FVC $\geq$ LLN; and normal RV and TLC

- obstructive lung disease (OLD)-FEV $/ F V C$ < LLN; normal or increased RV or TLC; or a positive bronchodilator response

- restrictive lung disease (RLD)-FVC $<\mathrm{LLN}$; $\mathrm{FEV}_{1} / \mathrm{FVC} \geq \mathrm{LLN}$; and reduced RV and TLC

- mixed obstructive and restrictive lung disease (MORLD) - FEV $_{1} /$ FVC $<$ LLN and reduced TLC

Bronchodilator response testing was performed in accordance with the Brazilian Thoracic Association guidelines, ${ }^{(11)}$ a significant bronchodilator response being characterized by the following:

- abnormal spirometry results showing a post-bronchodilator absolute change in $\mathrm{FEV}_{1}$ (post-bronchodilator $\mathrm{FEV}_{1}$ pre-bronchodilator $\mathrm{FEV}_{1}$ ) $\geq 200 \mathrm{~mL}$; an absolute variation in $\mathrm{FEV}_{1}$ in relation to the predicted value ([post-bronchodilator FEV - pre-bronchodilator $\left.\mathrm{FEV}_{1}\right] \times 100 /$ predicted FEV $\left._{1}\right)>7 \%$; and a post-bronchodilator absolute change in FVC (post-bronchodilator FVC - pre-bronchodilator FVC) $\geq 350 \mathrm{~mL}$

- normal spirometry results showing a post-bronchodilator change in $\mathrm{FEV}_{1}$ (postbronchodilator $\mathrm{FEV}_{1}$ - pre-bronchodilator $\left.\mathrm{FEV}_{1}\right) \geq 10 \%$

Data analysis was performed with the IBM SPSS Statistics software package, version 19.0 (IBM Corporation, Armonk, NY, USA). Quantitative variables were expressed as mean \pm standard deviation. Qualitative variables were expressed as absolute and relative frequencies. Pearson's test was used in order to assess correlations among spirometric variables, BMI-for-age $\mathrm{Z}$ scores, and waist circumference measurements in the OLD, RLD, and MORLD groups. Values of $p \leq 0.05$ were considered significant. The present study was approved by the local research ethics committee (Ruling no. 80/09), and the parents or legal guardians of all participants gave written informed consent.

\section{Results}

The study sample consisted of 59 individuals, the mean age being $11.7 \pm 2.7$ years. Of those 59 individuals, 30 (50.8\%) were male. In addition, 32 (54.2\%) were Mulatto, 22 (37.2\%) were Black, and $5(8.4 \%)$ were White. The BMl-for-age $\mathrm{Z}$ scores ranged from 1.2 SDs to $6.1 \mathrm{SDs}$, with a mean of $3.1 \pm 1.0\left(\mathrm{~kg} / \mathrm{m}^{2}\right)$. Therefore, of the 59 individuals studied, 4 (6.7\%) were classified as overweight, 28 (47.4\%) were classified as obese, and 27 (45.7\%) were classified as severely obese. Table 1 shows the lung function measurements in $\%$ of predicted.

Of the 59 individuals studied, 17 (30.3\%) had TLC values $<80 \%$ of predicted, whereas 2 (3.5\%) had TLC values > 120\%.

Of the 59 individuals studied, 15 (25.4\%) had a positive bronchodilator response (as determined by the change in $\left.\mathrm{FEV}_{1}\right), 10(67.0 \%)$ of those 15 individuals being severely obese (Table 2). They all had $\mathrm{FEV}_{1} / \mathrm{FVC}$ values below the LLN, being therefore classified as having OLD. The change in FVC (i.e., post-bronchodilator FVC pre-bronchodilator FVC) characterized a positive bronchodilator response in only 2 individuals, and none of the patients with MORLD had a positive bronchodilator response. One of the individuals with a positive response was unable to undergo measurement of lung volumes.

Considering $\mathrm{FEV}_{1}$ a predictor of bronchial obstruction, we analyzed the changes occurring in absolute and percent predicted FEV $_{1}$ after bronchodilator use. The results are shown in Table 3.

We examined the relationship between lung disease and the degree of obesity in the study sample. The results are shown in Table 4.

Pearson's correlation analysis was performed in order to determine whether the anthropometric measurements (i.e., BMl and waist circumference) correlated with the spirometric variables in the OLD, RLD, and MORLD groups. The results 
Table 1 - Lung function measurements (in percentage of predicted values) in 59 overweight children and adolescents with normal lung function, obstructive lung disease, restrictive lung disease, or mixed obstructive and restrictive lung disease. ${ }^{\mathrm{a}}$

\begin{tabular}{lcccccccccc}
\hline \multirow{2}{*}{$\begin{array}{c}\text { Lung } \\
\text { function }\end{array}$} & \multicolumn{2}{c}{$\mathrm{FEV}_{1}$} & \multicolumn{2}{c}{ FVC } & \multicolumn{2}{c}{ FEV $_{1} / F V C$} & FEF $_{25-75 \%}$ & TLC & RV \\
\cline { 2 - 11 } Normal & $95.43 \pm$ & $95.10 \pm$ & $93.05 \pm$ & $90.16 \pm$ & $86.81 \pm$ & $88.67 \pm$ & $64.86 \pm$ & $66.86 \pm$ & $91.40 \pm$ & $89.65 \pm$ \\
& 10.89 & 12.19 & 9.51 & 11.40 & 3.44 & 2.79 & 14.38 & 15.14 & 8.70 & 27.43 \\
OLD & $86.26 \pm$ & $89.74 \pm$ & $93.06 \pm$ & $92.95 \pm$ & $76.42 \pm$ & $80.47 \pm$ & $51.42 \pm$ & $60.63 \pm$ & $99.00 \pm$ & 118.56 \\
& 13.23 & 17.19 & 13.51 & 15.50 & 5.09 & 7.40 & 14.35 & 22.30 & 13.55 & \pm 47.53 \\
RLD & $75.33 \pm$ & $79.27 \pm$ & $72.20 \pm$ & $74.27 \pm$ & $88.80 \pm$ & $89.21 \pm$ & $57.33 \pm$ & $64.20 \pm$ & $69.38 \pm$ & $66.62 \pm$ \\
& 13.08 & 14.54 & 14.30 & 15.56 & 4.88 & 5.80 & 12.88 & 18.27 & 7.95 & 42.53 \\
MORLD & $73.50 \pm$ & $80.50 \pm$ & $83.25 \pm$ & $86.00 \pm$ & $74.25 \pm$ & $78.75 \pm$ & $45.25 \pm$ & $55.50 \pm$ & $71.75 \pm$ & $37.25 \pm$ \\
& 5.91 & 12.15 & 4.19 & 13.24 & 3.86 & 3.86 & 8.57 & 14.40 & 11.89 & 41.99 \\
\hline
\end{tabular}

Bd: bronchodilator; OLD: obstructive lung disease; RLD: restrictive lung disease; and MORLD; mixed obstructive and

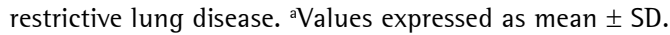

Table 2 - Respiratory function variables (in percentage of predicted values) in 15 children and adolescents showing changes in $\mathrm{FEV}_{1}$.

\begin{tabular}{ccccccccccc}
\hline Individual & \multicolumn{2}{c}{ FEV $_{1}$} & \multicolumn{2}{c}{ FVC } & \multicolumn{2}{c}{ FEV $_{1} / F V C$} & \multicolumn{2}{c}{ FEF $_{25-75 \%}$} & TLC & RV \\
\cline { 2 - 10 } & Pre-Bd & Post-Bd & Pre-Bd & Post-Bd & Pre-Bd & Post-Bd & Pre-Bd & Post-Bd & Pre-Bd & Pre-Bd \\
\hline 01 & 85 & 94 & 101 & 102 & 71 & 78 & 53 & 65 & 95 & 62 \\
02 & 84 & 91 & 87 & 89 & 79 & 84 & 58 & 75 & 86 & 78 \\
03 & 94 & 102 & 100 & 101 & 78 & 83 & 72 & 80 & 94 & 71 \\
04 & 101 & 110 & 108 & 112 & 80 & 83 & 70 & 81 & 104 & 99 \\
05 & 103 & 110 & 111 & 114 & 78 & 82 & 69 & 82 & 119 & 150 \\
06 & 100 & 108 & 101 & 100 & 81 & 89 & 80 & 110 & 89 & 31 \\
07 & 70 & 94 & 70 & 95 & 85 & 83 & 33 & 40 & & \\
08 & 69 & 78 & 83 & 91 & 70 & 73 & 35 & 43 & 79 & 70 \\
09 & 68 & 78 & 75 & 78 & 75 & 80 & 38 & 47 & 84 & 106 \\
10 & 92 & 103 & 112 & 108 & 69 & 79 & 48 & 60 & 124 & 171 \\
11 & 84 & 96 & 83 & 90 & 84 & 88 & 69 & 69 & 80 & 74 \\
12 & 80 & 98 & 89 & 102 & 77 & 81 & 56 & 74 & 78 & 46 \\
13 & 86 & 101 & 94 & 92 & 78 & 93 & 51 & 75 & 128 & 235 \\
14 & 86 & 97 & 87 & 93 & 82 & 86 & 62 & 78 & 104 & 169 \\
15 & 70 & 82 & 68 & 70 & 95 & 100 & 44 & 80 & 73 & 103 \\
\hline
\end{tabular}

Bd: bronchodilator.

are shown in Table 5. There was a significant negative correlation between the anthropometric measurements and the $\mathrm{FEV}_{1} / \mathrm{FVC}$ ratio in the individuals with MORLD.

\section{Discussion}

In the present study, we evaluated the lung function of overweight children and adolescents with normal chest X-rays and without respiratory symptoms or a history of respiratory disease. Pulmonary function test results were abnormal in $64.4 \%$ of the sample, OLD having predominated (in $32.2 \%$ ). This suggested that obesity affected respiratory function. In addition, the proportion of normal spirometry results was lower in the individuals who were severely obese than in those who were overweight or obese.

Bronchodilator response was observed in 25.4\% of the individuals studied, suggesting the presence of reversible OLD. Although 2 patients had a substantial bronchodilator response, neither had any disease to which airway hyperresponsiveness might have been attributed. The use of exhaled nitric oxide or induced sputum in order to assess airway inflammation might contribute to explaining this finding.

It has been reported that $\mathrm{FEF}_{25-75 \%}$ is a predictor of small airway obstruction. ${ }^{(14)}$ Pre- and postbronchodilator $\mathrm{FEF}_{25-75 \%}$ were below the LLN in $51(86.4 \%)$ and $41(69.4 \%)$, respectively, of the 
individuals analyzed in the present study. This suggests that OLD and bronchodilator response occurred mainly at the level of the small airways. The diagnosis of OLD in the present study was primarily based on spirometric data rather than on TLC. This was due to the fact that only 2 of the participants had a TLC of more than $120 \%$ of predicted, a finding suggesting that

Table 3 - Changes in FEV in the 15 overweight children and adolescents with a positive bronchodilator response.

\begin{tabular}{ccc}
\hline Individual & $\Delta \mathrm{FEV}_{1}, \mathrm{~mL}^{*}$ & $\Delta \mathrm{FEV}_{1}, \%^{* *}$ \\
\hline 01 & 260 & 9 \\
02 & 180 & 7 \\
03 & 310 & 8 \\
04 & 260 & 9 \\
05 & 210 & 7 \\
06 & 350 & 8 \\
07 & 420 & 24 \\
08 & 270 & 9 \\
09 & 240 & 7 \\
10 & 290 & 11 \\
11 & 310 & 12 \\
12 & 570 & 18 \\
13 & 380 & 15 \\
14 & 370 & 11 \\
15 & 260 & 12 \\
\hline
\end{tabular}

${ }^{*}$ Mean $\pm \mathrm{SD}=312 \pm 96.7 \mathrm{~mL} .{ }^{* *}$ Mean $\pm \mathrm{SD}=11.1 \pm 4.7 \%$.

Table 4 - Lung function in the study sample, by degree of obesity. ${ }^{\mathrm{a}}$

\begin{tabular}{llll}
\hline $\begin{array}{c}\text { Lung } \\
\text { function }\end{array}$ & $\begin{array}{c}\text { Overweight/ } \\
\text { obese }\end{array}$ & $\begin{array}{c}\text { Severely } \\
\text { obese }\end{array}$ & \multicolumn{1}{c}{ Total } \\
\hline Normal & $14(23.7)$ & $07(11.8)$ & $21(35.5)$ \\
OLD & $09(15.2)$ & $10(16.9)$ & $19(32.2)$ \\
RLD & $07(11.8)$ & $08(13.5)$ & $15(25.4)$ \\
MORLD & $02(3.3)$ & $02(3.3)$ & $04(6.7)$ \\
\hline
\end{tabular}

OLD: obstructive lung disease; RLD: restrictive lung disease; and MORLD: mixed obstructive and restrictive lung disease. ${ }^{a}$ Values expressed as $\mathrm{n}(\%)$. the individuals with OLD had less hyperinflation and, therefore, less severe disease.

We found a significant negative correlation between the anthropometric and spirometric variables in the individuals with MORLD. However, this was found in only a small number of participants, further studies being therefore required.

We found studies describing and quantifying lung function changes, with conflicting results. Saxena et al. ${ }^{(15)}$ studied young adults and reported that lung function changes occur in overweight individuals and are proportional to the degree of obesity. According to Ora et al., ${ }^{(16)}$ reduced lung volumes in adults appear to be associated with obesity and predispose to increased airway resistance and decreased expiratory flow.

Spathopoulos et al. ${ }^{(17)}$ in a cohort study involving children in Greece, investigated the influence of obesity on pulmonary function, as well as a possible association of obesity with atopy and asthma. Teixeira et al. ${ }^{(18)}$ found significant changes in the slow vital capacity and peak expiratory flow of obese children and adolescents. El-Baz et al. ${ }^{(19)}$ investigated the impact of obesity and body fat distribution on lung function in Egyptian children and found that respiratory symptoms were more common in the children who were overweight than in those who were normal weight. The authors also found significant RLD, small airway obstruction, respiratory muscle dysfunction, and increased airway resistance in the overweight children. ${ }^{(19)}$ However, no such association was found in other studies. Bertolini and Koseki ${ }^{(20)}$ found no correlation between lung function and anthropometric measurements in moderately obese children. Pekkarinen et al. ${ }^{(21)}$ investigated individuals over 18 years of age and found no correlation between body composition and spirometric changes; however, the authors

Table 5 - Correlations between anthropometric and spirometric variables in the obstructive lung disease, restrictive lung disease, and mixed obstructive and restrictive lung disease groups.

\begin{tabular}{|c|c|c|c|c|c|c|c|c|c|c|c|c|}
\hline \multirow{4}{*}{$\begin{array}{c}\text { Spirometric } \\
\text { variables }\end{array}$} & \multicolumn{12}{|c|}{ Anthropometric variables } \\
\hline & \multicolumn{6}{|c|}{ Waist circumference } & \multicolumn{6}{|c|}{ Body mass index } \\
\hline & \multicolumn{2}{|c|}{ OLD } & \multicolumn{2}{|c|}{ RLD } & \multicolumn{2}{|c|}{ MORLD } & \multicolumn{2}{|c|}{ OLD } & \multicolumn{2}{|c|}{ RLD } & \multicolumn{2}{|c|}{ MORLD } \\
\hline & $r$ & $\mathrm{p}$ & $r$ & $\mathrm{p}$ & $r$ & $\mathrm{p}$ & $r$ & $\mathrm{p}$ & $r$ & $\mathrm{p}$ & $r$ & $\mathrm{p}$ \\
\hline $\mathrm{FEV}_{1}$ & 0.064 & 0.795 & 0.331 & 0.228 & 0.628 & 0.371 & -0.092 & 0.709 & 0.146 & 0.603 & 0.434 & 0.566 \\
\hline FVC & 0.048 & 0.845 & 0.250 & 0.369 & 0.645 & 0.355 & -0.127 & 0.603 & 0.091 & 0.747 & 0.461 & 0.539 \\
\hline $\mathrm{FEV}_{1} / \mathrm{FVC}$ & 0.095 & 0.700 & 0.113 & 0.689 & -0.996 & 0.004 & -0.219 & 0.367 & 0.106 & 0.708 & -0.986 & 0.014 \\
\hline $\mathrm{FEF}_{25-75 \%}$ & 0.055 & 0.823 & 0.265 & 0.341 & -0.667 & 0.333 & 0.203 & 0.405 & 0.358 & 0.190 & -0.527 & 0.473 \\
\hline
\end{tabular}

OLD: obstructive lung disease; RLD: restrictive lung disease; and MORLD: mixed obstructive and restrictive lung disease. 
reported a negative correlation between waist circumference and the $\mathrm{FEV}_{1} / \mathrm{FVC}$ ratio. Finally, according to Boran et al., ${ }^{(22)}$ a likely explanation for these discrepant findings is the fact that most studies investigate extreme levels of obesity or have a small sample size, with no control groups.

The high prevalence of lung disease in the present study is consistent with some of the data from the studies cited herein, given that reduced chest compliance, increased abdominal pressure, early airway collapse, and increased airway resistance are expected in overweight individuals. ${ }^{(23)}$ These changes can explain why overweight individuals have lung disease (OLD, RLD, or MORLD). According to Lopes, ${ }^{(24)}$ inflammatory processes mediated by cytokines produced by adipocytes are responsible for pulmonary changes, characterized by airway hyperresponsiveness, among others. This observation is in agreement with those of El-Baz et al., ${ }^{(19)}$ who defined fat as a metabolically active tissue.

In a study investigating biomarkers of lung function in overweight adolescents with asthma, ${ }^{(25)}$ weight loss was shown to reduce the concentration of adiponectin (an anti-inflammatory mediator), especially in cases of visceral obesity; to increase $\mathrm{FEV}_{1}$ and FVC; and to improve asthma symptoms. In a study investigating mildly obese children, Boran et al. ${ }^{(22)}$ reported that 3 of the children had reversible OLD (as determined by pulmonary function test results), despite having no previous respiratory symptoms or atopic diseases; the authors also reported that, given the lack of provocation tests, further studies were needed in order to determine whether obesity caused or increased airway hyperresponsiveness. In the present study, participants were not screened for atopy and no bronchial provocation tests were performed; however, the number of individuals with a bronchodilator response was higher in the present study than in the study conducted by Boran et al. ${ }^{(22)}$

The pathophysiology of obesity-related lung changes includes changes resulting from restricted lung expansion caused by lipid deposition, with decreased alveolar surface area, and reducing functional residual capacity. ${ }^{(26)}$ Therefore, the etiopathogenesis of OLD in obese individuals appears to involve mechanical and inflammatory processes. Studies have examined the association between asthma and obesity in an attempt to determine whether it is due to reduced lung volumes or increased airway resistance resulting in asthma-like symptoms. ${ }^{(27)}$

Camilo et al. ${ }^{(28)}$ reported that obesity is not the only factor responsible for the development and increased prevalence of asthma. Other important factors, such as genetic factors, immunological factors, and environmental factors, should be considered in future studies. Story ${ }^{(29)}$ reported that airway inflammation, mechanical changes secondary to obesity, and airway hyperresponsiveness, as well as changes in diet and physical activity, are related to the development of asthma in overweight individuals. Story ${ }^{(29)}$ also reported that obesity increases the severity of asthma and reduces the quality of life in obese children, having reported that further studies are needed in order to clarify the relationship between asthma and obesity. In our study, this finding was considered relevant, given that the study sample consisted of patients without respiratory disease or symptoms.

The present study has limitations that should be considered. One limitation is the number of participants, which can be partly explained by the difficulty in finding individuals meeting the inclusion criteria. Another limitation is related to the use of the helium dilution method for measuring lung volumes. The method is known to underestimate lung volumes by not measuring the volume of air in areas of air trapping excluded from ventilation. This, however, is of little or no significance, given that the study sample consisted of young patients with normal chest $X$-rays and no history of respiratory disease. Yet another limitation is the difficulty in choosing reference values for the age group under study. Because there are no universally recommended values, we used parameters that are generally accepted in the literature. Finally, there was no control group in the present study; Pereira ${ }^{(12)}$ established reference values, and those were used here. Therefore, lung function should be further investigated in longitudinal studies involving samples that are similar to our study sample, in order to determine the risk of lung disease by means of bronchial provocation tests, measurement of DLCO, and determination of immune, hormonal, and inflammatory mediators.

Because pulmonary function tests provide objective data on lung function, ${ }^{(3)}$ they are essential in the management of individuals with respiratory dysfunction and in individuals at risk 
of developing respiratory dysfunction, as is the case of overweight individuals. The combination of spirometry and lung volume measurements should be the method of choice for the evaluation of lung function, given that it is the best and most comprehensive method for measuring lung function, allowing a reliable diagnosis of lung disease. This combination should therefore be part of the routine care of such patients.

In conclusion, the prevalence of lung disease in overweight children and adolescents was high in the present study, OLD having predominated. The bronchodilator response observed in the present study was greater than was that reported in the literature, a positive bronchodilator response being more common in the individuals who were severely obese than in those who were obese or overweight.

\section{References}

1. Nishida C, Mucavele P. Monitoring the rapidly emerging public health problem of overweight and obesity: the WHO Global Database on Body Mass Index. SCN News. 2005;29:5-12.

2. Coutinho WF. Consenso Latino-Americano de Obesidade. Arq Bras Endocrinol Metab. 1999;43:21-67. http://dx.doi. org/10.1590/S0004-27301999000100003

3. Melo SM, Melo VA, Menezes Filho RS, Santos FA. Efeitos do aumento progressivo do peso corporal na função pulmonar em seis grupos de índice de massa corpórea. Rev Ass Med Bras. 2011;57(5): 509-15. http://dx.doi. org/10.1590/S0104-42302011000500007

4. Lin CK, Lin CC. Work of breathing and respiratory drive in obesity. Respirology. 2012;17(3):402-11. PMid:22212441. http://dx.doi.org/10.1111/j.1440-1843.2011.02124.x

5. Lazarus R, Colditz G, Berkey CS, Speizer FE. Effects of body fat on ventilator function in children and adolescents: cross-sectional findings from a random population sample of school children. Pediatr Pulmonol. 1997; 24(3):187-94. http://dx.doi.org/10.1002/ (SICl)1099-0496(199709)24:3<187::AID-PPUL4>3.0.C0;2-K

6. Ray CS, Sue DY, Bray G, Hansen JE, Wasserman K. Effects of obesity on respiratory function. Am Rev Respir Dis. 1983;128(3): 501-6. PMid:6614644

7. Instituto Brasileiro de Geografia e Estatística - IBGE [homepage on the Internet]. Brasilia: Instituto Brasileiro de Geografia e Estatística. [updated 2008; cited 2013 Sep 1] Características Étnico-Raciais da População. Um estudo das categorias de classificação de cor ou raça Available from: htpp://www.ibge.gov.br/

8. Fernández JR, Redden DT, Pietrobelli A, Allison DB. Waist circumference percentiles in nationally representative samples of African-American, European-American, and Mexican-American children and adolescents. J Pediatr. 2004;145(4): 439-44. PMid:15480363. http://dx.doi. org/10.1016/j.jpeds.2004.06.044

9. de Onis M, Onyango AW, Borghi E, Siyam A, Nishida C, Siekmann J. Development of a WHO growth reference of school-aged children and adolescents. Bull World Health
Organ. 2007;85(9):660-7. PMCid:PMC2636412. http:// dx.doi.org/10.2471/BLT.07.043497 PMid:18026621

10. Standardization of Spirometry, 1994 Update. American Thoracic Society. Am J Respir Crit Care Med. 1995;152(3):1107-36. PMid:7663792. http://dx.doi. org/10.1164/ajrccm.152.3.7663792

11. Sociedade Brasileira de Pneumologia e Tisiologia. Diretrizes para testes de função pulmonar. J Pneumol. 2002; 28(Suppl 3):S83-S238.

12. Pereira CA. Espirometria. J Pneumol. 2002; 28(Suppl 3):S1-S82.

13. Pennock BE, Cottrel JJ, Rogers RM. Pulmonary function testing. What is 'normal'? Arch Intern Med. 1983;143(11):2123-7. PMid:6639231. http://dx.doi. org/10.1001/archinte.143.11.2123

14. Leite JM. Obesidade Infantil e Alterações das Provas Funcionais Respiratórias. [thesis]. Covilhã: Universidade da Beira Interior; 2009.

15. Saxena Y, Sidhwani G, Upmanyu R. Abdominal obesity and pulmonary functions in young Indian adults: a prospective study. Indian J Physiol Pharmacol. 2009;53(4):318-26. PMid:20509323

16. Ora J, Laveneziana P, Wadell K, Preston M, Webb KA, O'Donnell DE. Effect of obesity on respiratory mechanics during rest and exercise in COPD. J Appl Physiol (1985). 2011;111(1):10-9. PMid:21350021. http://dx.doi. org/10.1152/japplphysiol.01131.2010

17. Spathopoulos D, Paraskakis E, Trypsianis G, Tsalkidis A, Arvanitidou V, Emporiadou M, et al. The effect of obesity on pulmonary lung function of school aged children in Greece. Pediatr Pulmon. 2009;44(3): 273-80. PMid:19208374. http://dx.doi.org/10.1002/ ppul.20995

18. Teixeira VS, Fonseca BC, Pereira DM, Silva BA, Reis FA. Avaliação do efeito da obesidade infantil e a do adolescente sobre as propriedades ventilométricas e força muscular do sistema respiratório. ConScientiae Saude. 2009;8(1):35-40.

19. El-Baz FM, Abdelaziz EA, Abdelaziz AA, Kamel TB, Fahmy A. Impact of Obesity and Body Fat Distribution on Pulmonary Function of Egyptian Children. Egypt J Bronchol. 2009;3(1):49-58.

20. Bertolini SM, Koseki LC. Capacidade pulmonar e força muscular respiratória em crianças obesas. Saude Pesquisa. 2011;4(2):169-76.

21. Pekkarinen E, Vanninen E, Länsimies E, Kokkarinen J, Timonen KL. Relation between body composition, abdominal obesity, and lung function. Clin Physiol Funct lmaging. 2012; 32(2):83-8. PMid:22296626. http:// dx.doi.org/10.1111/j.1475-097X.2011.01064.x

22. Boran P, Tokuc G, Pisgin B, Oktem S, Yegin Z, Bostan 0 . Impact of obesity on ventilatory function. J Pediatr (Rio J). 2007; 83(2):171-6. PMid:17426872. http:// dx.doi.org/10.2223/JPED.1609

23. Littleton SW. Impact of Obesity on Respiratory Function. Respirology. 2011;17(1):43-9. PMid:22040049. http:// dx.doi.org/10.1111/j.1440-1843.2011.02096.x

24. Lopes HF. Hipertensão e inflamação: papel da obesidade. Rev Bras Hipertens. 2007;14(4):239-44.

25. da Silva PL, de Mello MT, Cheik NC, Sanches PL, Correia FA, de Piano A, et al. Interdisciplinary therapy improves biomarkers profile and lung function in asthmatic obese adolescents. Pediatr Pulmonol. 2012;47(1):8-17. PMid:22170805. http://dx.doi.org/10.1002/ppul.21502 
26. Koenig SM. Pulmonary complications of obesity. Am J Med Sci. 2001;321(4):249-79. http:// dx.doi.org/10.1097/00000441-200104000-00006 PMid:11307867

27. Jones RL, Nzekwu MM. The effects of body mass index on lung volumes. Chest. 2006;130(3):827-33. PMid:16963682. http://dx.doi.org/10.1378/chest.130.3.827
28. Camilo DF, Ribeiro JD, Toro AD, Baracat EC, Barros Filho AA. Obesity and Asthma: Association or Coincidence ? J Pediatr (Rio J). 2010;86(1):6-14. http://dx.doi.org/10.2223/ JPED. 1963

29. Story RE. Asthma and obesity in children. Curr Opin Pediatr. 2007;19(6):680-4. PMid:18025936. http:// dx.doi.org/10.1097/MOP.0b013e3282f1ddfa

\section{About the authors}

\section{Silvana Neves Ferraz de Assunção}

Anesthesiologist. Professor Edgard Santos University Hospital, Federal University of Bahia School of Medicine, Salvador, Brazil.

Carla Hilário da Cunha Daltro

Endocrinologist. Professor Edgard Santos University Hospital, Federal University of Bahia School of Medicine, Salvador, Brazil.

\section{Ney Christian Boa Sorte}

Pediatrician. Professor Edgard Santos University Hospital, Federal University of Bahia School of Medicine, Salvador, Brazil.

\section{Hugo da Costa Ribeiro Júnior}

Gastroenterologist. Professor Edgard Santos University Hospital, Federal University of Bahia School of Medicine, Salvador, Brazil.

\section{Maria de Lourdes Bastos}

Pulmonologist. Professor Edgard Santos University Hospital, Federal University of Bahia School of Medicine, Salvador, Brazil.

\section{Cleriston Farias Queiroz}

Cytologist. Professor Edgard Santos University Hospital, Federal University of Bahia School of Medicine, Salvador, Brazil.

\section{Antônio Carlos Moreira Lemos}

Pulmonologist. Professor Edgard Santos University Hospital, Federal University of Bahia School of Medicine, Salvador, Brazil. 